\title{
Tóth György'
}

\section{A halál folyamata, halottakkal kapcsolatos elsődleges teendők a prehospitális sürgősségi ellátásban}

\author{
The Process of Death, the Primary Tasks Related to \\ the Dead in Pre-Hospital Emergency Care
}

\begin{abstract}
Absztrakt
A sürgösségi ellátás prehospitális szakaszának egyik legnehezebb feladata a halál megállapitása, az életmüködések hiányával kapcsolatos döntések és az ehhez kapcsolódó dokumentációk teljesítése. A halált közvetlenül megelöző tünetek felismerése segithet a megelözésben, az újraélesztést a beteg megmentése, a várható siker érdekében végezzük, azonban a körülmények, a kiváltó tényezők, a helyszíni lehetöségek adott esetben akadályozhatják az erőfeszitéseinket.

A közlemény célja, hogy összefoglalja a halál bekövetkezését elöidézö, szervezetben zajló folyamatokat, segitse az életmüködések hiányának felismerését, iránymutatást nyújtson a halottak körüli teendökkel kapcsolatban a kórházon kívüli környezetben, megemlitve a helyszíni dokumentációhoz kapcsolódó változtatási igényt is.
\end{abstract}

Kulcsszavak: halál, halálmegállapítás, természetes halál, rendkivüli halál, halottvizsgálat

\section{Abstract}

One of the most difficult tasks in emergency care is to diagnose death, make decisions about the lack of life functions, and fulfil related documentation. Recognition of the symptoms that immediately precede death can help in prevention, and resuscitation is performed to save the patient, for the expected success, however, circumstances, triggers, and on-site opportunities may hinder our efforts. 
The purpose of the article is to summarise the processes in the body that cause death, to help identify the lack of vital functions, and to provide guidance on what to do about the dead in an out-of-hospital setting, including the need for changes to on-site documentation.

Keywords: death, determination of death, natural death, extraordinary death, examination of the dead

\section{Bevezetés}

A halál megállapítása, az életműködések hiányát észlelő ellátó döntései és helyszíni tevékenysége a kórházon kívüli sürgősségi ellátás egyik nehéz és fontos teendői közé tartozik, amelynek jelentőségét tovább növeli a helyszín, a kárhely jellegzetességéből, adott esetben a betegek, sérültek számából adódó nehezített körülmény is. Lehetőségünk szerint azonnal tisztázandó, hogy a beteg életműködései fennállnak-e, igy annak pótlásával, az újraélesztés megkezdésével biztosithatjuk az életfontosságú szervek működésének helyreállítását. Az újraélesztési kísérlet ellenére sikertelen, illetve az észlelt körülmények miatt a nem megkezdett ellátás a halál tényének megállapításával, a kötelező dokumentációs és az elhunyttal kapcsolatos egyéb tevékenységekkel folytatódik.

\section{A halál kialakulása, folyamata}

Az életmüködések megszünése a kiváltó kórfolyamat zajlásdinamikájától függően lassan, akár órák, napok elteltét követően is kialakulhat, illetve hirtelen, teljes „jólét" közepette vagy az előidéző agresszió, trauma, valamint az adott kórkép szervet ért müködészavara következtében hirtelen is jelentkezhet.

ABC-instabilitásra, a halál közelségére, azaz a periarreszt állapotra utaló tünetek észlelése rendkívül fontos a beteg adekvát ellátásához, amelyet az életműködések fenntartása céljából, illetve az állapotstabilizálás érdekében végzünk. Súlyos sérülés esetén, illetve a helyszínen végleges ellátási lehetőség hiányában sokszor meg kell elégednünk azzal, hogy a beteg állapota nem romlik tovább, a kórkép progresszióját csökkentettük, a további definitív ellátás a választott gyógyintézetben történik.

\subsection{Periarreszt állapotra utaló riasztó tünetek}

A szervezetben zajló akut változások időben történő észlelése segíti a felkészülésünket a légzés-/keringésmegállásra, ugyanakkor azonnali beavatkozással megakadályozhatjuk az egymást rontó folyamatok következtében kialakuló halálos kimenetelt.

Riasztó tünetek lehetnek az alábbiak:

- mozdulatlanság, rendellenes testhelyzet;

- eszmélet- vagy tudatzavar;

- jelenlétünkben zajló görcsroham; 
- nehezített légzés, légzőmozgások látható hiánya;

- nagyfokú sápadtság, szederjesség;

- jelentős, látható vérzés;

- az életfontos szervek elégtelenségének egyéb, látható jelei. ${ }^{2}$

\subsection{A halál mint folyamat}

Amikor a légzés, a keringés és az agymüködés zavara miatt a szervezet visszafordíthatatlan felbomlása megindul, azt a halál bekövetkezésének tekintjük. Bár az életműködések megszűnése egy adott pillanatban történik, mégis a halál lezajlását, az életmüködések megszűnését követő időszakot folyamatjellegként értékeljük.

Az idő előrehaladtával a szervezetben, a testben zajló változások külső, látható és vizsgálható jeleket eredményezve egyértelművé teszik a visszafordíthatatlan folyamatot, a halál kezdeti szakaszában fennálló reverzibilitás lehetősége azonnali ellátásra, az életműködések pótlására, ezáltal az újraélesztés megkezdésére sürget.

A légzés, a keringés vagy az agy működésének átmeneti megszűnését, amely nem jelenti a halál vagy az agyhalál beálttát, a klinikai halál időszakának nevezzük, tehát az életműködések megszủnését követően azok helyreállítására biológiailag megalapozott reményünk van. ${ }^{3}$

A klinikai halál jelentkezésének időpontja pontosan meghatározható, amely egybeesik az életmüködések megszűnésének pillanatával, azonban az átmenet a klinikai halál és a halál között nehezen meghatározható, külső jelek, tünetek alapján nem állapítható meg, kivéve, ha a halál bekövetkezésének egyértelmü jeleit észleljük - élettel összeegyeztethetetlen sérülés -, ekkor az életmüködések megszűnése egyben a sérült halálát is jelenti.

Amennyiben szakember nem szemtanúja a légzés-keringés megállásának, a bekövetkezésének pontos ideje a klinikai halál időszakában, illetve a halálra utaló gyanújelek észlelésekor nem állapítható meg, ugyanis a beteg látható eszméletvesztése, mozdulatlansága, görcsrohama nem feltétlenül jelenti az életműködések azonnali megszűnését. Életműködések hiányában tehát a feladatunk, hogy mérlegeljük a reverzibilitás lehetőségét, és haladéktalanul kezdjük el az újraélesztést.

A beteg folyamatos észlelése lehetőséget ad számunkra, hogy a fent említett riasztó tünetek mellett a klinikai halál fenyegető közelségére utaló jeleket is felismerhessük, ezáltal megszakithatjuk a törvényszerüen progresszív folyamatot, illetve felkészülhetünk a beteg újraélesztésére.

Gyakran fellépő, a klinikai halált közvetlenül megelőző tünetek:

- a légzés kifejezett romlása, a légzés jellegének, típusának megváltozása-az erőlködő, lassú mellkasmozgásokkal járó, úgynevezett gaspoló vagy terminális légzés már a keringésmegállás közvetlen jele -, akár hirtelen fellépő fuldoklás;

- a bőrszín hirtelen megváltozása, hűvössé válása, mindemellett kifejezett verejtékezés megjelenése;

Göbl Gábor: Oxiológia. Budapest, Medicina, 2006. 109-110.

1997. évi CLIV. törvény az egészségügyről. 216. §. 
- az addig tapintható pulzus gyengévé, irregulárissá, akár igen gyérré válása;

- monitorozott betegen észlelhető, klinikai halállal fenyegető ritmuszavar (periarrest arrhythmiák);

- nagy mellkasi fájdalom, súlyos fejfájás;

- szubjektíven észlelt halálfélelem, megsemmisülésérzés, hirtelen jelentkező gyengeségérzés;

- görcsroham (Morgagni-Adams-Stokes-szindróma). ${ }^{4}$

\subsection{Halálra utaló gyanújelek, klinikai tünetek és bizonyossági jelek}

Amennyiben nem vagyunk szemtanúi a halál bekövetkezésének, már a beteg - akár nagyobb távolságból történő - megpillantásakor látható jelek is felvethetik a halál gyanúját, ilyenek:

- mozdulatlanság,

- rendellenes testhelyzet,

- sápadtság vagy nagyfokú szederjesség,

- nem látható mellkasmozgások,

- tág pupillák.

A halál gyanújeleinek észlelése azonnali, további vizsgálatot indikál, amennyiben nem észlelhetőek a halál bizonyosságát jelentő kórbonctani jelenségek, mint a beivódásos hullafoltok, a hullamerevség, a rothadás, mumifikáció vagy az élettel összeegyeztethetetlen sérülések jelenléte.

A fentiek mutatják, ha nem mi vagyunk a szemtanúi az életmüködések megszünésének, nem lehetünk biztosak abban, hogy pontosan mikor történt, hiszen a bizonyossági haláljelenségek - kivéve az élettel összegyeztethetetlen sérülést - csak később, akár órák elteltével jelentkeznek. Amennyiben az első ellátó rövid időn belül érkezik a halálozás helyszínére, bizonyossági jelek hiányában azonnali újraélesztést kell kezdenie, amennyiben egyéb, az újraélesztést mérlegelhető tények nem válnak ismertté, azaz a szervezet végleges biológiai elöregedettsége, ismert és bizonyosan halálos betegség végstádiuma, illetve olyan, bizonyosan hosszú agyi oxigénhiánnyal járó állapot, amely a reverzibilitást kizárhatja (beszorult, életmúködések nélküli sérült elhúzódó kimentése).

\section{Halál megállapítása a helyszínen}

A halál megállapítása során - bizonyossági haláljelek hiányában - figyelembe kell vennünk azokat a körülményeket is, amelyek a halál kialakulásában szerepet játszhattak, illetve befolyásolhatják az életmüködések megszűnését követő, szervezetben zajló változásokat. Ilyen körülmény lehet a halált okozó baleseti mechanizmus vagy

Göbl (2006) i. m. 112-113. 
kórfolyamat, az anamnézis hiánya, illetve a környezeti jellemzők (elsősorban a hőmérséklet) és azok a testre gyakorolt hatásai.

Súlyos sérülést követő gyakori halálokok a légút, illetve a légzés zavarát okozó kórfolyamatok, mint az eszméletvesztést követő légúti elzáródás, súlyos mellkasi traumát követő feszülő pneumothorax vagy pericardialis tamponade kialakulása, továbbá olyan súlyos belső (csillapíthatatlan) vagy külső vérzés, amely rövid időn belül a sérült elvérzését okozza. Ezen okok egy része a helyszínen időben felismerve, adekvát ellátással korrigálható, így a párhuzamosan végzett újraélesztést sikeressé teheti. A szív- és érrendszeri, illetve akut légzészavart okozó kórképek következtében jelentkező légzés-keringés megállása szintén reverzibilis lehet. Azokban a belgyógyászati balesetekben (baleseti lehülés, víz alá merülés), toxikológiai kázusok (alkohol-/gyógyszermérgezések) gyanújában, ahol az eszmélet- és tudatzavar, légút- és légzészavar, a test hőmérsékletének csökkenése is szerepet játszik a halál kialakulásában, szükség lehet a beteg folyamatos újraélesztése mellett történő gyógyintézetbe szállítására, ezen esetekben a halál megállapítása nem a helyszínen történik. ${ }^{5}$

A halál gyanújelei észlelése során (bizonyossági jelek hiányában) az életmüködések azonnali ellenőrzése történik, amelyet az aktuális alap- és emelt szintü újraélesztési irányelvek fogalmaznak meg, emellett igyekszünk kizárni az irreverzibilitás, az újraélesztés „el nem kezdésének” lehetőségét, hiszen az első teendőnk a spontán keringés helyreállítása, amennyiben erre megalapozott reményünk van.

\subsection{Az életmüködések vizsgálata a halál megállapításának folyamatában}

Az életműködések vizsgálatát a szabályoknak megfelelően, külső tényezők hatásától mentesen, körültekintően végezzük, amely során a légzés-keringés hiányát állapítjuk meg. A légzés vizsgálata a légútbiztositást (a fej hátrahajtását, adott esetben az áll kiemelését) követően hármas érzékeléssel történik, a beteg légzőnyílásaihoz legalább $5 \mathrm{~cm}$-es távolságra hajolva figyeljük a mellkas mozgását, hallhatjuk, és az arcunkon érezhetjük a légzônyílásokból kiáramló levegőt, amennyiben normális légzést észlelünk.

Kompetens személy a légzés vizsgálatával párhuzamosan a beteg keringését is értékeli a centrális pulzus - nyaki verőér - tapintásával, illetve egyéb, látható jelek észlelésével, mindezek hiányában a fentiek értelmében döntünk a további teendőkröl. A halál megállapításához az eszköz nélküli vizsgálómódszerek mellett eszközök használatára is törekszünk, optimálisan az életműködések vizsgálata közben EKGdefibrillátor egység előkészítése történik. Az eszközös vizsgálat célja az életmüködések megszűnésének hátterében álló ritmuszavar felismerése, szükség esetén annak megszüntetése, párhuzamosan az újraélesztés megkezdésével. A halál megállapítása során a szív elektromos és mechanikus tevékenységének hiányát is igazolnunk kell - valamennyi elvezetésben asystolia, azaz isoelektromos vonal látható -, amely 
vizsgálatokat 15 perc elteltével megismételni szükséges (mind az eszköz nélküli, mind az eszközös vizsgálat tekintetében). ${ }^{6}$

\section{A halál fogalmának jogi, illetve szakmai értelmezései}

A halál fogalmai jogszabály értelmezése alapján:

- klinikai halál: a légzés, a keringés vagy az agy müködésének átmeneti megszünése, amely nem jelenti a halál vagy az agyhalál beálltát;

- agyhalál: az agy - beleértve az agytörzset is - müködésének teljes és visszafordíthatatlan megszúnése;

- halál: amikor a légzés, a keringés és az agymüködés teljes megszünése miatt a szervezet visszafordíthatatlan felbomlása megindul;

- baleset: baleset az emberi szervezetet ért olyan külső hatás, amely a sérült akaratától függetlenül következik be, és halált okoz.

Szakmai szempontok szerint megkülönböztethetünk hirtelen halált, amely teljes jólét közepette, látszólag egészséges egyén rövid időn belül bekövetkezett halála - általánosan 24 órán belül vagy hamarabb -, illetve váratlan halált, amely ismert, akár krónikus betegségben szenvedő beteg előre nem látható, nem várt halála, amelyet egyaránt okozhat az idült vagy rejtetten zajló kórfolyamat akut szövődménye.

A természetes és nem természetes halált a jogszabály a fennálló kritériumok alapján fogalmazza meg, azaz a természetes módon való bekövetkezését a körülmények kétségessé teszik, így

- a halál tekintetében büncselekményre utaló adat merül fel, vagy

- rendkívüli halálnak minősül, azaz:

- a halált baleset okozta, vagy a körülmények arra utalnak;

- a halált öngyilkosság okozta, vagy a körülmények arra utalnak;

- a halál bekövetkezésének előzményei, körülményei ismeretlenek, és nem állnak rendelkezésre olyan adatok, amelyekből megalapozottan következtetni lehet a halál természetes okból történő bekövetkeztére;

- fogvatartott elhalálozása esetén.

A személyazonosság megállapításáig a rendkívüli halál esetén követendő eljárást kell alkalmazni, ha az elhunyt személyazonossága ismeretlen. ${ }^{7}$

Baleset következtében bekövetkező halálozás minden esetben rendkívülinek minősül, így ennek megfelelően hatósági eljárás, illetve hatósági boncolás történik. Büncselekmény elkövetésekor, illetve annak gyanúja esetén a büntetőeljárás szabályai szerint igazságügyi orvosi boncolást kell elrendelni, amelynek célja a halál okának, bekövetkezése körülményeinek tisztázása.

Természetes halál esetén tehát nem merül fel büncselekményre utaló jel, illetve nem kétséges a halál természetes bekövetkezése, halottvizsgálat keretében történik

Tóth György: Actual issues of determination of death and examination of the dead on the scene of major accidents and catastrophes. Hadtudományi Szemle, 10. (2017), 4. 550-565.

1997. évi CLIV. törvény az egészségügyröl. 216-217. §. 
az elhunyttal kapcsolatos további intézkedés. A halottvizsgálat feladata a halál tényének megállapítása, a halál feltételezett okáról, bekövetkezésének idejéről történő nyilatkozattétel, illetve a rendkívüli körülmények, a rendkívüli halál felismerése, amely esetén az ügyben eljáró hatóság azonnali értesítése szükséges.

\subsection{A halálmegállapítás, halottvizsgálat személyi feltételei}

A jelenlegi szabályozás, az érvényben lévő jogszabályok a halál tényének megállapítására orvost és mentőtisztet hatalmaznak fel, a halottvizsgálat elvégzésére kizárólag orvos jogosult, aki lehet:

- egészségügyi intézményben vagy egészségügyi intézménybe (intézményből) betegszállító szolgáltató jármüvén történő halálozás esetén a beteget ellátó vagy felvételére illetékes, továbbá a beteget elbocsátó fekvőbeteg-osztály vagy járóbeteg-ellátó egység orvosa vagy az intézet vezetője által e feladattal megbízott orvos, ügyeleti időben az ügyeleti szolgálatot ellátó orvos vagy a helyszínre érkezett mentőegység orvosa;

- a mentőszolgáltató mentőfeladatot teljesítőjárművén-a halál bekövetkezésének tényét a mentőegység orvosa vagy mentőtisztje állapítja meg - a mentőorvos, ennek hiányában a haláleset helyéhez legközelebb eső, patológiai osztállyal rendelkező fekvőbeteg-gyógyintézet e feladattal megbízott orvosa;

- a Magyar Honvédség, katonai nemzetbiztonsági szolgálat, rendvédelmi szerv vagy a Nemzeti Adó- és Vámhivatal fegyveres rendvédelmi feladatokat is ellátó szervezetének felügyelete alá tartozó területen, épületben, zárt alakulaton belül - a haláleset helyétől függően - a Magyar Honvédség, a katonai nemzetbiztonsági szolgálat, a rendvédelmi szerv vagy a Nemzeti Adó- és Vámhivatal egészségügyi szolgálatának orvosa, ha az nem áll rendelkezésre, a haláleset helye szerint illetékes háziorvos vagy ezen szolgálat ügyeletes orvosa;

- közterületen, járművön vagy egyéb nyilvános helyen a haláleset helye vagy a holttest jármüről való leemelésének helye szerint illetékes háziorvos, illetve ezen szolgálat ügyeletes orvosa;

- üzemorvos, iskolaorvos vagy szociális ellátó intézmény által foglalkoztatott orvos, ha nem elérhető, a haláleset helye szerint illetékes háziorvos vagy ezen szolgálat ügyeletes orvosa;

- egyéb helyen a haláleset helyszínére vagy a holttest jármüröl való leemelésének helyére a legrövidebb időn belül hívható háziorvos vagy ezen szolgálat ügyeletes orvosa;

- a szülést levezető orvos. ${ }^{8}$

A fenti felsorolásból szembetűnő, hogy a halálozás helyszínének számos lehetősége változatosan határozza meg a halottvizsgálatra kötelezett orvos személyét. 


\section{Természetes halál esetén szükséges teendők}

Természetes halál esetén a halottvizsgálatot végző orvos teendői az alábbiak:

- a törvényi feltételek fennállása esetén kezdeményezi az elhunyt kórbonctani vizsgálatát;

- megkezdi az elhunyt egészségügyi adatainak a beszerzését;

- az elhunyt egészségügyi adatainak ismeretében - amennyiben lehetséges -

- megállapítja a halál okát, és kitölti a halottvizsgálati bizonyítványt;

- megkísérli értesíteni az elhunyt eltemettetésére kötelezettet a halál tényéről;

- kezdeményezi a holttest elszállítását;

- értesíti a haláleset tényéről és az elhunyt ismert adatairól az illetékes települési önkormányzatot;

- értesíti a szervkivételre kijelölt egészségügyi intézmény szervkoordinátorát.

A holttest vizsgálata a halál okának, bekövetkezési idejének és módjának felderítésére szolgál, lépései megegyeznek az élő beteg vizsgálatával, miközben fokozott figyelem hárul a rendkívüli körülmények felismerésére is.

A holttest környezetének vizsgálata során búcsúlevél, méregmaradványok, mérgező anyagok, alkohol, gyógyszerek, erőszakos cselekményt okozó eszközök, a nyílászárók, látható testváladékok keresése és azonosítása történik, amit a ruházat, illetve azon található szennyeződések vizsgálata követ.

A holttest teljes felszínének ruházat nélkül történő átvizsgálása szükséges valamennyi látható, tapintható, észlelhető elváltozás felismerése érdekében, különös tekintettel a hajas fejbőr, a nyálkahártyák, illetve a testnyílások megtekintésére. A látható sérülések, hegek jól azonosítható jellemzőkkel történő leírása, pontos dokumentációja a későbbi azonosíthatóság érdekében kiemelt jelentőséggel bír.

\subsection{Dokumentáció helyszíni halálozás esetén}

A halottakkal kapcsolatos dokumentáció során a halál tényét az "Igazolás a halál megállapításról" dokumentumon tölti ki a halált megállapító mentőtiszt, ${ }^{9}$ míg az orvos „Halottvizsgálati bizonyítvány"-t állít ki.

Az előbbi, a halál megállapítást igazoló dokumentum a beteg helyszíni ellátásával, vizsgálatával kapcsolatban kitöltött esetdokumentáció mellékleteként szerepel, amely tartalmazza:

- a beteg személyes adatait;

- lakcímét és a halálozás helyét;

- a halál bekövetkezésének idejét;

- a halál bekövetkezésének körülményeit, a felderíthető anamnézist;

- a látható külsérelmi nyomokat;

- az ellátást;

Az Országos Mentőszolgálat Szervezési és Módszertani Osztályának 3. sz. Egészségügyi Szakmai Útmutatója alapján, 89.0296/1999, 1999. december 30. 
- a halál megállapítását végző adatait, a mentőegységre vonatkozó információkat.

A dokumentum az észlelő mentőtiszttől a halál bekövetkezésének időpontját kéri, azonban teljes bizonyossággal a halál észlelésének idejéről tud nyilatkozni. Amennyiben nem szemtanúként észlelte a halál beálltát, arról csak óvatos becsléssel tehet megállapítást, amelyhez alaposabb jártasság szükséges.

A jelenleg érvényes formátum (1. ábra) - amely 1999 óta érvényes az Országos Mentőszolgálatnál - módosítása kívánatos lenne az alábbi kiegészítésekkel:

- a „halál beálltának időpontja” helyett a "halál észlelésének időpontja”;

- az „anamnesis" rovat módosítandó az alábbiakkal:

- halál kialakulásának körülményei - például észlelő jelenléte, hogyan találtak rá, milyen testhelyzetben;

- ismert betegségek, illetve szövődmények, amelyek feltételezhetően a halálhoz vezettek;

- a halált megelőző állapot - például eszméletvesztés, mellkasi fájdalom, nehézlégzés, sérülés esetén annak mechanizmusa;

- külsérelmi nyomok, látható sérülések részletes leírása;

- látható bizonyossági haláljelek;

- rendkívüli körülmények jelenléte;

- további intézkedés kezdeményezése - hatóság, háziorvos, orvosi ügyelet - és annak időpontja;

- csatolt dokumentumok:

- mentési dokumentációs lap másodpéldánya;

- EKG-felvétel;

- értékleltár (2. ábra).

A jelenlegi szabályozás egyetlen példány kitöltését írja elő, azonban szükség lenne mind a helyszínen, mind a beteg tárolt egészségügyi dokumentumai közé is elhelyezni egy példányt (önátírós másolati példány formájában).

Amennyiben a helyszínen újraélesztés történik, a keringésmegállás körülményeiröl is szükséges dokumentáció végzése, amelyet az Utstein formula ${ }^{10}$ határoz meg, a helyszínen kitöltendő dokumentumban nyilatkozni szükséges az újraélesztés mellőzésének okáról is, amennyiben nem észlelhető a bizonyossági haláljelek közül a hullamerevség, illetve a test oszlása, bomlási folyamatainak jelentkezése - például elhúzódó betegség végstádiuma, végelgyengülés, élettel összeegyeztethetetlen sérülés.

10 A hazai újraélesztések - kórházon belüli és kívüli egyaránt - adatainak összegyüjtése, feldolgozása az egységes szemlélet kialakításának, az ellátás kontrolljának, fejlesztésének, tudományos eredmények értékelésének céljából. 


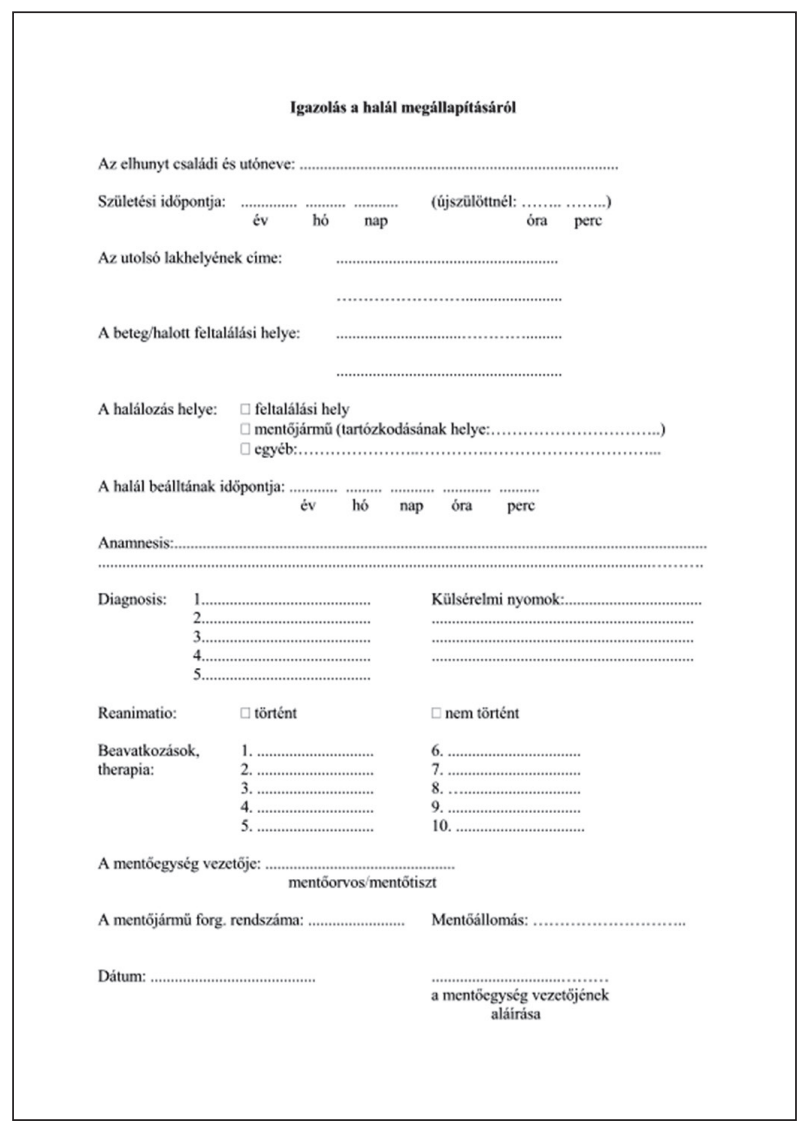

1. ábra: Igazolás a halál megállapításáról

Forrás: Az Országos Mentőszolgálat Szervezési és Módszertani Osztályának 3. sz. Egészségügyi Szakmai Útmutatója (1999) i. m.

A halottvizsgálati bizonyítvány részletesen tartalmazza:

- az elhunyt és a hozzátartozó személyes adatait;

- a halálozás helyét, időpontját;

- a kezelőorvos, illetve a halottvizsgálatot végző orvos nevét, beosztását, munkahelyét;

- kórbonctani vizsgálat, illetve hatósági eljárás szükségének megjelölését;

- a vizsgálat vagy eljárás indokát és egyéb megjegyzéseket;

- a kiállítás keltét, a halottasházba szállítás időpontját, a temetés engedélyezett idejét;

- rendőrhatósági álláspontot;

- hamvasztásra vonatkozó engedélyt;

- a halál okának megállapítását végző orvos minősítését (patológus, kezelőorvos);

- boncolás megtörténtét; 
- a halálhoz vezető betegségek sorozatát, a betegségek, állapotok kialakulásának időpontját;

- a halálozás jellegét;

- a sérülésre vonatkozó információkat (időpontja, helyszíne, módja, körülményei);

- a terhesség tényét és az időtartamát;

- a kiállítás keltét, aláirást, pecsétet és egyéb megjegyzéseket.

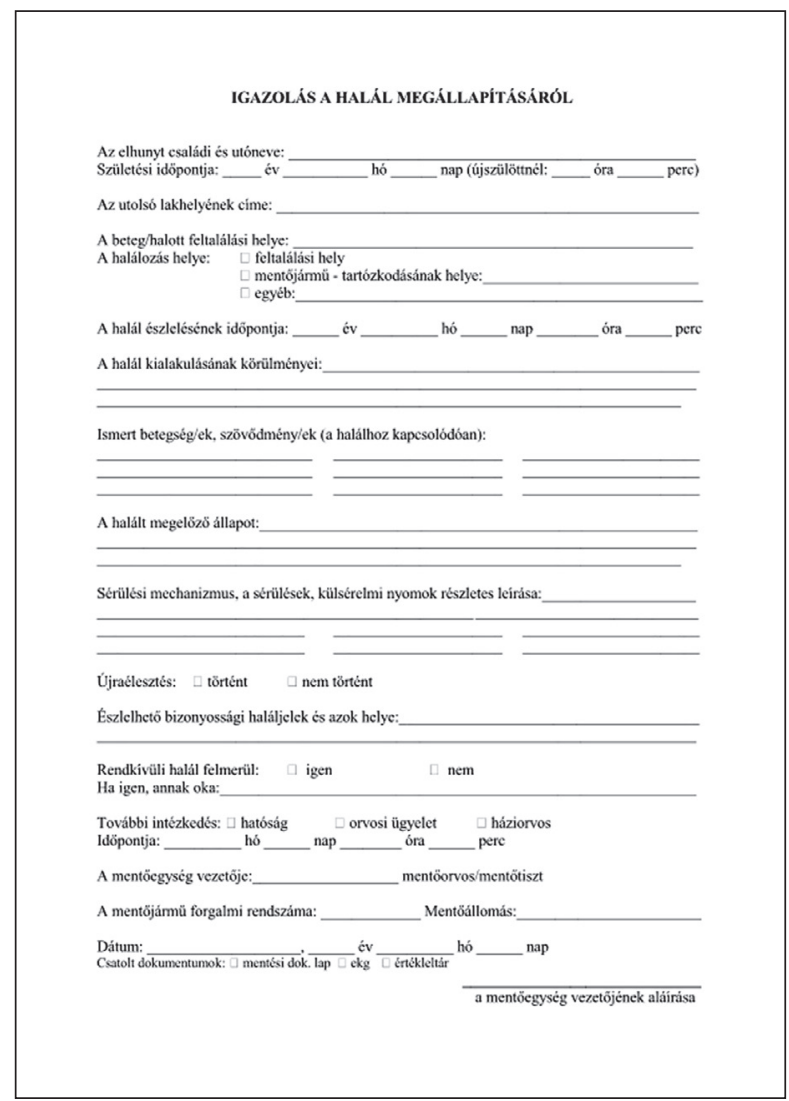

2. ábra: Javaslat az „Igazolás a halál megállapitásáról” dokumentum módositására

Forrás: a szerző szerkesztése

Perinatális halottvizsgálati bizonyítványt szükséges kitölteni az újszülöttről, aki a születést követő 168 órán belül halt meg, valamint a halva született, illetve szülés közben elhunyt magzatról, amely a halottvizsgálati bizonyítványtól eltérően tartalmazza a magzat vagy újszülött fö-, illetve egyéb betegségét vagy állapotát, főbb és egyéb anyai betegséget, állapotot, amely a magzatot vagy az újszülöttet érinti, eröszakos haláleset jellegét, helyszínét és módját, illetve sérülés esetén annak jellegét és az érintett testtájékokat. 
A kórbonctani vizsgálat célja a halál bekövetkezését megelőzően kialakult valamennyi kóros állapot részletes vizsgálata és a betegség megállapítása, a népesség megbetegedési és halálozási okainak feltárása, az egészségügyi ellátás során alkalmazott diagnosztikai és gyógyító eljárások hatékonyságának ellenőrzése, az orvosi és gyógyszerészeti tudomány fejlődésének elősegítése.11

A halottvizsgálat és az azt követő dokumentáció során az egyik legfontosabb kérdés, hogy boncolás kezdeményezése történjen-e, illetve az adott helyzetben lehetőség van-e arra, hogy annak mellőzésével a halottvizsgálat lezárható. Jogszabály rendelkezik arról, hogy mely esetekben kötelező, illetve milyen lehetőségek teszik lehetővé a boncolás mellőzését, ennek megfelelően kötelező a boncolás:

- rendkívüli halál, illetve annak gyanúja esetén, tehát:

- ha a halál tisztázatlan körülmények között történt;

- büncselekmény vagy annak gyanúja fennáll;

- közlekedési, foglalkozási baleset gyanújában;

- egészségügyi ellátással összefüggésbe hozható halálozás során;

- egyéb baleset, mérgezés esetén;

- öngyilkosság jelentkezésekor;

- fogvatartott halálozását követően;

- ismeretlen személyazonosságú halott esetén;

- egyéb esetekben, mint:

- perinatális halálozás során;

- transzplantációt követően donor vagy recipiens halála történt;

- nagy értékü, beépített eszköz található az elhunyt testében;

- tudományos, oktatási cél indokolja;

- hamvasztás esetén, ha a mellőzését nem kérik;

- hozzátartozó kérésére.

Mellőzhető a boncolás az alábbi esetekben:

- természetes, ismert okkal, kórházi halálozás esetén a kezelőorvos és a patológus javaslatára a kórház igazgatója engedélyezi;

- természetes, ismert okkal, kórházon kívüli halálozás esetén a háziorvos, ügyeletes orvos javaslatára a tisztiorvos engedélyezi;

- hozzátartozói kérésre, amennyiben tudományos vagy oktatási céllal történne, illetve hamvasztás miatt szükséges lenne. ${ }^{12}$

A fentiek tükrében látható, milyen nagy a jelentősége annak, hogy a halálmegállapítás és a halottvizsgálat kiegészül-e kórbonctani vizsgálattal vagy anélkül zárul le, amihez a kórházon kívüli halálesetek tekintetében sok esetben „egyszemélyes” helyszíni döntés vezet. 


\section{Teendők rendkívüli halál esetén}

Rendkívüli halállal kapcsolatos hatósági eljárás lefolytatása szükséges, illetve kormányrendeletben meghatározottak szerint hatósági boncolást kell elrendelni, amennyiben a halál okának, bekövetkezése körülményeinek tisztázása szükséges.

Az elsődleges és a halaszthatatlan intézkedéseket a holttest megtalálásának helye szerint illetékes első fokú rendőri szerv teszi meg a halálesetröl kapott bejelentés alapján. Amennyiben szükséges, a tevékenységirányítási központ intézkedik a bejelentés valódiságának lehetőség szerinti ellenőrzéséről és - amennyiben még nem történt meg - orvos, mentők, indokolt esetben a katasztrófavédelem, egyéb szervek (például gázművek, elektromos művek, vízirendészet) értesítéséről, a helyszín biztosításáról, a további eljárási cselekményeket foganatosító bizottság összeállításáról, valamint helyszínre küldéséröl.

A helyszín biztosításáról és a szemle megtartásáról, valamint az elhunyttal kapcsolatos egészségügyi adatok beszerzéséről és rögzítéséről is haladéktalanul gondoskodni kell a háziorvos, kezelőorvos tájékoztatása alapján, a hozzátartozók által, illetve a rendelkezésre álló egészségügyi dokumentációk jegyzőkönyvhöz történő csatolásával.

A szemlebizottság köteles a szemlét olyan részletességgel lefolytatni és rögzíteni, hogy az - ha a későbbi eljárás során büncselekmény gyanúja merül fel - a keletkezett dokumentációkkal megfeleljen a büntetőeljárási jog szabályai szerint lefolytatott helyszíni szemle alaki és tartalmi követelményeinek, a helyszínröl, a holttest eredeti állapotáról és fontosabb részleteiről jegyzőkönyvet, fénykép-, hangfelvételt és helyszínrajzot vagy helyszínvázlatot kell készíteni.

A szemle során fel kell kutatni és rögzíteni kell a holttesten és környezetében található mindazon tárgyakat, nyomokat, anyagmaradványokat és elváltozásokat, amelyek a halál okának és bekövetkezése körülményeinek bizonyítására alkalmasak.

Amennyiben a szemle során bủncselekmény gyanúja merül fel, vagy a körülmények arra utalnak, azt azonnal meg kell szakítani, és haladéktalanul jelenteni kell a tevékenységirányítási központ felé. A szemlét elsősorban a halottszemlével kell kezdeni, amelyen kötelező biztosítani a helyszíni halottvizsgálatot végző orvos részvételét, aki lehet a Nemzeti Szakértői és Kutató Központ orvosszakértője, háziorvos, ügyeletes orvos vagy a rendőrség alkalmazásában álló orvos. A halál feltehető okának és a holttesten lévő esetleges sérüléseknek a megállapítása érdekében a vizsgálat a holttest lemeztelenített állapotában, lehetőség szerint az eredeti megtalálási helyén történik.

A haláleset helyszínére hívott rendőr intézkedik, hogy a helyszíni halottvizsgálatra kötelezett egészségügyi szolgálat illetékes orvosa a halottvizsgálatot elvégezze. $\mathrm{Ha}$ a haláleset helyszínére hívott rendőr az elsődleges adatok és körülmények alapján - különös tekintettel a halottvizsgálatot végző orvos véleményére - azt állapítja meg, hogy a haláleset nem rendkivüli, az előzetes vizsgálat lefolytatását egyéb körülmény nem indokolja, úgy a megállapításokról jelentést készít. A rendőrhatósági eljárás lefolytatásának mellőzését a halottvizsgálati bizonyítvány megfelelő rovatában is rögzíteni kell. ${ }^{13}$ 
A fenti jogszabály értelmében a halálozás különleges körülményeinek megállapítása, illetve rendkívüliségének kizárása tehát az elsőként helyszínre érkező rendőr feladata (segíti a döntést a halottvizsgálatot végző orvos), amely aggályos lehet, s bizonyos esetekben akár a tévedés lehetőségét is magában hordozhatja.

\section{Következtetések}

Az életműködések megszűnését megelőző élettani folyamatok, illetve azok irreverzibilis változásainak felismerését, az újraélesztés sikertelenségét követi a halál tényének megállapítása, a bekövetkezési módjának, valamint a feltételezett okának a tisztázása, amely a sürgősségi ellátás részeként megkezdődik és folytatódik a helyszíni halottvizsgálat során. Az ehhez kapcsolódó további tevékenységek alapvetően a halál természetes vagy nem természetes bekövetkezésétől függenek, amihez a pontos és megfelelő dokumentáció alapvető jelentőségü. A halál megállapítását követő teendők ismerete valamennyi, a kórházon kívüli ellátást végző szakember számára elengedhetetlen a megfelelő döntések meghozatalában és az ahhoz kapcsolódó tevékenységek tekintetében is.

\section{Felhasznált irodalom}

Campbell, John Emory: Basic Trauma Life Support. New Jersey, Upper Saddle River, 2004. Göbl Gábor: Oxiológia. Budapest, Medicina, 2006.

Kereszty Éva Margit: A halottakra vonatkozó betegjogi szabályozás és ennek problémái a magyar jogban. Orvosi Hetilap, 153. (2012), 9. 330-338. DOI: https://doi. org/10.1556/OH.2012.29316

Tóth, György: Actual issues of determination of death and examination of the dead on the scene of major accidents and catastrophes. Hadtudományi Szemle, 10. (2017), 4. 550-565.

\section{Jogi források}

1997. évi CLIV. törvény az egészségügyröl

24/2014. (VII. 11.) ORFK utasítás a rendkívüli halál esetén követendő rendőri eljárásról.

351/2013. (X. 4.) Korm. rendelet a halottvizsgálatról és a halottakkal kapcsolatos eljárásról

89.0296/1999. számú, Az Országos Mentőszolgálat Szervezési és Módszertani Osztályának 3. sz. Egészségügyi Szakmai Útmutatója 1999. december 30. 